\title{
The Role of Librarians as Information Literacy Instructors: A Case of Kaduna State University, Kaduna
}

\author{
Dr. Maimuna Izah \\ National Institute for Legislative and Democratic Studies, Abuja \\ Tel: +2348035889731Ｅ-mail: maimunahu@yahoo.com
}

\begin{abstract}
Information literacy is a set of abilities requiring individuals to recognize needed information to possess the ability to locate, evaluate, and use these information ethically. The study assesses information literacy of academic staff in a public university using the role of librarians as its nexus. Training - feedback mechanism was used. Questionnaire was used for data collection which was administered on 104 academic staff who participated in the information literacy programme of Kaduna State University, Kaduna. The data was analyzed descriptively. The study revealed the training session covered what is expected, the trainees stated that the length of the session was right, however, the training was mired by poor Internet services. The study recommends among others, the sufficient Internet bandwidth, alternative power supply by the university management, and support for academic staff participation in information literacy training programmes by the respective heads of departments.
\end{abstract}

Keyword: Information literacy, academic staff, public university, electronic resources

DOI: $10.7176 / \mathrm{NMMC} / 91-05$

Publication date:July 30th 2020

\section{Introduction}

In recent years, the role of librarian has included instruction on the use of electronic resources irrespective of place where they i.e., public, academic, school, national and privately owned libraries. These librarians are traditionally evaluators and service providers of information and knowledge. Emphases on academic libraries, which comprised libraries found in tertiary institutions such as degree and diploma awarding institutions have revealed high expectations of librarians. These academic libraries are expected to play crucial roles in promoting and developing information competency and literacy skills of their users through their respective librarians. These staff should be proactive in promoting their abilities as information experts by facilitating and supporting students and staff navigate their ways through an ever increasing information channels. Their role specific is to ensure that confusion leading to information anxiety and overload are addressed considerably.

One of such role is the task of information literacy. Information literacy according to the American Library Association cited in Omar (2012) include "set of abilities requiring individuals to recognize when information is needed and have the ability to locate, evaluate and use effectively the needed information". The definition has exposed us to other underlying requirements such as information seeking, ethics and use. Therefore, we can say that information seeking and usage have become complex process for tertiary institution students and even lecturers due to the proliferation of information technologies and availability of electronic resources of all types and formats that necessitate information literacy. The ethical considerations of information literacy is adduced by it feedback mechanism which thrust is to develop skills that would equip and avail the ability to locate and retrieve information for use. Erich (2014) under the component of Information Literacy, American Association of School Libraries (AASO) states that literate students access information:

- Efficiently and effectively

- Evaluate information critically and competently

- Use information accurately and creatively

The case of students, researchers and lecturers relying on search engines such as Google, mamma, and yahoo as their sources of information is rampant in Kaduna state university despite the effort of the library's information literacy programmes focused of training on how to effectively and efficiently utilize the subscribed digital and non-digital resources for academic purposes. Efforts are intensified because Kaduna State University have invested huge amount of money to purchase or subscribe to many academic online databases that contain peer reviewed/ scholarly journals, in addition to other open access database that have inbuilt self-evaluation, accuracy and creativity parameters. It is expected that such resources should be fully utilized after possessing literacy training that exposes them through thorough search skills that can make them become more specific to locate relevant information from a variety of sources.

Information seeking and usage have become complex process for university students and academic staff due to factors such as proliferation of information technologies and availability of electronic resources of all types and in different formats. These have made it necessary for academic staff and students to develop skills that should equip 
them with the ability to locate and retrieve information in order to utilize the information effectively, efficiently and ethically. These attributes constitutes the basic thrust of the Kaduna State university library information literacy thrust.

\subsection{Brief history of the Kaduna State University}

Kaduna State University, Kaduna was established in 2004. There are two campuses, one in Kaduna and the other in Kafanchan. The university has a total of seven faculties, six departments and a college of remedial programmes in both campuses. The staff strength consists of 372 full time academic staff, 716 full time nonacademic staff and 28 sabbatical staff. There are over 7,846 undergraduate students 1950 postgraduate students, and 2000 remedial students. The university library subscribes to online and offline electronic resources. These subscribed resources comprised, AGORA, HINARI, Science Direct, Ebrary/Proquest, EBSCOHOST, and JSTOR. The Offline databases include E-granary and TEEAL. The library also subscribe to resources promoted and indexed by Scopus, Questa and Springer.

To help in the training of library stakeholders to equip them with the requisite skills that should make them benefit from access and retrieving of full text and disseminated messages from the diverse subscribed electronic resource training was staggered in phases. The training starts with training the librarians who were expected to train the staff and students. A period training programme that last for about two weeks is usually initiated with the issuance of invitation letters sent to all departments informing them about scheduled training, dates and time slated for each department. The training for academic staff is based on the assumption that these categories of staff have basic knowledge of computer operations, and therefore would find it easy to follow all the procedures to access and use of the subscribed electronic resources. However, for retrospection, handout containing the list of categorized databases and simple instruction on how to use the databases and other electronic resources were given.

Every session, the training starts with academic staff and usually take place in the Electronic library (elibrary) Unit of the university main library in Kaduna campus, between 9 am to 12 noon. The training focus on the following resources::

1. Access to Global Online Research in Agriculture(AGORA)

2. HINARI

3. Science Direct

4. EBRARY/ROQUEST

5. Scopus

6. Questa

7. EBSCOHOST

8. Springer

9. JSTOR

10. Off line database: E- Granary and TEEAL

\subsection{Objective of the study}

The objectives of the study are as follows:

1. To assess how effective information literacy programs are in terms of presentation, hands out, coverage of what is expected

2. To find out any problem faced by the library in carrying out the training

3. To proffer suggestions on how to improve the information literacy instructions

\subsection{Literature Review}

Justifying the need for information literacy, Adeleke (2010) pointed out that the only way that academic libraries can help students learn to work in a digital environment is training the users on how to access e-resources in the library. He further stated that the delivery of information literacy instruction is therefore necessary due to the vast array of e-resources. Similarly, Mar-Rounds (2015) posits that in higher education information literacy is gaining increasing importance due to the fact that the complexity and volumes of information necessitates skills to be displaced by three different sub-groups- the student body, teaching faculty and library staff.

The importance of information literacy instruction according to Birth (2012) is to provide students and faculty staff the practical skills needed to locate, retrieve, use and evaluate information completely, ethically and effectively. Furthermore, he stated that the skills gained through the instruction may be applied over a wide range of information needs and demands that are placed upon the students through the course of their studies as well as their professional and personal pursuits. McAskill (2008) also noted that students need to develop the framework 
that will allow them to become self-sufficient citizens who can locate, critically evaluate, and effectively use information.

Odede and Zawedde (2018), posited that in the fast-growing knowledge society, information literacy skills have become one of the most important skills. This is because students with research information needs will most likely use electronic resources if they have the skills required for their effective use. The findings revealed that the use of electronic information resources is determined by competency in the various dimensional constructs of information literacy.

A study by Adeleke and Eeahara (2016) revealed that there is a significant relationship between information literacy skills and use of electronic information resources, they also stated that it is evident that postgraduate students need to be assisted by stake holders to acquire the needed electronic information literacy skills, provide unmediated access to effectively use and benefit from the myriads of electronic information resources available to them to improve the quality of their academic and research.

\subsection{Methodology}

The research method adopted was survey method. The instruments used to collect the data were questionnaire. The instrument consists of six (6) questions. However, four (4) of the questions were close ended from which only one choice should be selected from the options, whereas the remaining two questions are open ended questions each. The instrument was administered to the participants on the last day of the training. These study target academic staff whose population amounted to one hundred and four (104). The training started from $15^{\text {th }}$ October to $4^{\text {th }}$ November, 2016. Analysis of the data was descriptive expressed as frequency distributions and their respective percentage.

\subsection{Results and Discussions}

The result of the responses after analysis are given as follows:

Table 1. Did the sessions covered what you expected?

\begin{tabular}{|l|l|l|}
\hline & Frequency & Percentage \\
\hline Yes & 103 & $99.0 \%$ \\
\hline No & 1 & $0.96 \%$ \\
\hline Total & $\mathbf{1 0 4}$ & $\mathbf{1 0 0 \%}$ \\
\hline
\end{tabular}

It was obvious from table 1 that the participants $103(99 \%)$ attained from the literacy training their expectations, however, only $1(0.96 \%)$ indicated otherwise. This implied that the literacy training had achieved the desired objectives.

Table 2. Presentation of the training

\begin{tabular}{|l|l|l|}
\hline Ranking of presentation & Frequency & Percentage \\
\hline Excellent & 43 & $41.3 \%$ \\
\hline Good & 61 & $58.6 \%$ \\
\hline Average & 0 & $0 \%$ \\
\hline Poor & 0 & $0 \%$ \\
\hline Total & $\mathbf{1 0 4}$ & $\mathbf{1 0 0} \%$ \\
\hline
\end{tabular}

Question on ranking the presentations is given in Table 2. Of the 104 respondents, 43(41.3\%) indicated that the presentation of the training was excellent, while $61(58.6 \%)$ indicated that the presentation was good. It can therefore be inferred that participant were pleased with the mode of the training and perhaps was able to benefit immensely.

Table 3. Length of session

\begin{tabular}{|l|l|l|}
\hline Length of presentation session & Frequency & Percentage \\
\hline Too long & 0 & $0 \%$ \\
\hline About right & 98 & $94.2 \%$ \\
\hline Too short & 6 & $5.76 \%$ \\
\hline Total & $\mathbf{1 0 4}$ & $\mathbf{1 0 0 \%}$ \\
\hline
\end{tabular}

Considering the engagement schedule of academic staff, it was pertinent to ensure that each presentation do not exceed the time allotted. The response of the academic staff on time allotted for the presentations in terms 
of it length is given in Table 3. It became important to elicit such opinions on the length of the training session so that modifications can be made to improve and appeal to the academic staff who shall be expected to honour the invitations periodically. Table 3 revealed that the majority of the academic staff $98(94.2 \%)$ stated that the length of the training session was about right, whereas $6(5.8 \%)$ stated that the length of the training was too short, and none complained that the length of the training session were too long. This responses implied that the scheduled length of each training should be sustained because majority were comfortable.

Table 4. Handouts

\begin{tabular}{|l|l|l|}
\hline Content of handout & Frequency & Percentage \\
\hline Excellent & 31 & $29.8 \%$ \\
\hline Good & 72 & $69.2 \%$ \\
\hline Average & 1 & $0.96 \%$ \\
\hline Poor & 0 & $0 \%$ \\
\hline Total & $\mathbf{1 0 4}$ & $\mathbf{1 0 0 \%}$ \\
\hline
\end{tabular}

To ensure that every participant follow, participants were given handouts of all the literacy training areas covered. The handout was also expected to facilitate the library to obtain the true rating of the content of the presentations to know when to move from basic to advance presentations, respectively. The result is given in Table 4. Majority $72(69.2 \%)$ of the participants indicated that the handout was good, while $31(29.8 \%)$ indicated that the handout was excellent, only $1(0.96 \%)$ indicated that it was average, and none said it was poor. The library literacy programme can then have influence on the extent of use as many can follow the procedure given to access and retrieve information resources subscribed for the use of the academic staff in the course of academic engagements.

Table 5. Best time to conduct training

\begin{tabular}{|l|l|l|}
\hline Best time to schedule literacy training & Frequency & Percentage \\
\hline Within the semester and morning hours & 101 & $97.11 \%$ \\
\hline Within the semester and after working hours & 1 & $0.96 \%$ \\
\hline During the semester break & 2 & $1.92 \%$ \\
\hline Total & $\mathbf{1 0 4}$ & $\mathbf{1 0 0 \%}$ \\
\hline
\end{tabular}

The training recognize the benefits of inclusion, and therefore, asked to know from the academic staff participating what should be the best time for the library to schedule literacy training for them. The responses are indicated in Table 5, and from the responses, it is obvious from the above responses that the best time to conduct training is within the semester and morning hours preferred by 101(97.11\%). Two $(1.92 \%)$ preferred the training to be scheduled during the semester break, and only one $(0.96 \%)$ preferred that it is held within the semester and after working hours. The findings have implications on the academic staff dispositions to self- development and academic activities, these could be the reasons expressed by the minorities. Many academic staff, gave reasons that since each department has its specific date to participate in the literacy training and is a maximum of two days, and the literacy training terminate after the schedule dates, many of them have benefited by simply visiting the library thereafter the trainings on their personal times to be guided by the library staff. That is why rescheduling their classes for those who have lectures from the morning to that convenient for their students do not in anyways jeopardized the university. As a matter of fact, it is the students that benefit with richer notes, lectures and sources of current information resources.

Table 6 provided answers to how the literacy training programme of KASU should be improved and what participants found most useful from the administered information literacy training. In the course of this assessment, academic staff were given freedom to respond in their own words without restructuring their thoughts. The first part allowed multiple responses, while the second part did not and it was found that in this part three participants did not respond for reasons best known to them.

The results revealed that improving the internet connectivity of the e-library the venue for the information literacy training is very important as attested by $130(49.05 \%)$ responses. Those who agitated for steady power supply accounted for $102(48.57 \%)$. The call for subscription to PubMed database was advanced by 5(2.38\%), which should emanate because the university has medical and medical related fields where PubMed plays a significant source of information which unfortunately the training did not cover. Honouring the invitation by these academic staff has helped the library to include this very important and significant source of electronic information. 
Table 6. How could the session be improved?

\begin{tabular}{|l|l|l|}
\hline What should the training session improve & Frequency * & Percentage \\
\hline Steady power supply & 102 & 48.57 \\
\hline Improve Internet connectivity & 103 & 49.05 \\
\hline Subscribe to Pub Med database & 5 & 2.38 \\
\hline Total & $\mathbf{2 1 0}$ & $\mathbf{1 0 0}$ \\
\hline $\begin{array}{l}\text { What participant found most useful from the information } \\
\text { literacy training }\end{array}$ & Frequency & Percentage \\
\hline Database & 19 & 18.81 \\
\hline EBSCOHOST & 8 & 7.92 \\
\hline Availability of Resource materials & 8 & 7.92 \\
\hline Sending materials to my mail & 4 & 3.96 \\
\hline Peer Review Journals & 3 & 2.97 \\
\hline Ebrary/Proquest session & 3 & 2.97 \\
\hline Everything about the training & 23 & 22.77 \\
\hline The search engines & 20 & 19.80 \\
\hline Access to e-books and journals & 8 & 7.92 \\
\hline Agora/Springer & 2 & 1.98 \\
\hline Not much & 3 & 2.97 \\
\hline Total & $\mathbf{1 0 1}$ & $\mathbf{9 9 . 9 9}$ \\
\hline
\end{tabular}

* Total frequency $=210$ due to multiple - choice answers

On the areas participants found most useful from the information literacy training, a large number $22.77 \%$ found everything about the training useful. Those who found using search engines closely followed (19.80\%), the use of databases followed third with $18.81 \%$ response, whereas the least were those who found the use of AGORA/Springer useful (1.98\%). The findings has helped the library drive to subscribing new electronic resources and prioritizing those already subscribed, as well as hoping that the submission when communicated to the university management would avail them fund the repositioning focus of the library. The library staff whose role is facilitation would also benefit when preparing to undertake such roles.

\subsection{Conclusion}

The findings showed that the training session covered what they expected, the presentation was good and they felt that the length of the training session was about right. It can be concluded that information literacy training play significant role in the reposition of academic library as well as helping the library staff to change according with the changing information technology, and developing befitting information literacy skills to enable them identify, retrieve, evaluate and use quality information resources.

\subsection{Recommendations}

The study identified problems that hinder effective performance of information literacy training such as the obstacles that must be solved to attain information literacy in developing countries where the study took place. The following recommendations are proffered:

1. Whenever there is a circular for notification for training, heads of Departments should ensure that all those who to benefit from the training are fully informed and reminded because many who came late gave accuses of either not aware or have forgotten.

2. Most databases subscribed by the library and accessible on-line, therefore, poor Internet services would mean incapability to use these facilities, therefore, the University management should provide sufficient Internet bandwidth within and outside the library to obtain value for the huge funds expended on these resources.

3. The library management should preferably organize training in the mornings and when students are on break or at the beginning of first semester. The one most preferred by the majority should take preference.

4. Training should be constantly organized for newly employed academic staff.

5. It is impossible to achieve the aim of electronic resources training when there is an interrupted power supply. Providing alternative power supply such as solar energy and inverter dedicated to the library is highly recommended. 


\section{References}

Adeleke, A. A., \& Olorunsola, R. (2010). "Training in the use of e-Resources in Academic Libraries: One University's Approach Library". Hi Tech News. No. 6/7 www.academia.edu

Adeleke, D. S., \& Emeahora, E. N. (2016). Relationship between Information Literacy and Use of Electronic Information Resources by Post Graduate Students in University of Ibadan. Retrieved from https://digitalcommons.unl.edu/libphilprac (December 3, 2019)

Birth, R. G. (2012). The Impact of Information Literacy Instruction on the Library and Information Competency of Graduate Students. Dissertation Submitted to The Faculty of Olivet Nazarene University School of Graduate and Continuing Students in partial Fulfillment of the Requirements for the Degree of Doctor of Education in Ethical Leadership. http://digitalcommons.olivet.edu diss (September 19, 2018).

Chigbu, E. D., \& Dim, C. L. (2012). Connectivity and Accessibility in Nigerian University Libraries: A Survey of Access, Usage and Problems in the University of Nigeria, Nsukka. Library Philosophy and Practice. www.webpages.uidaho.educ (September 19, 2018)

Erich, A., \& Popescus, C. (2014). The Impact of Information Literacy in the Academic Education Environment, www.lisr.ro/en (October 13, 2019)

Kaduna State University. 2014/2015 Annual Report. A compilation of the Directorate of Academic Planning.

Mar-Rounds, G. (2015). Better Understanding of Teaching Faculty's Beliefs and Behaviour towards Information Literacy: The University of South Pacific Perspective. IFLA Library Theory and Research Section. www.ifla.org (October, 15, 2019)

McAskill, W. (2008) 'Information Literacy: The Leadership Role of Academic Librarian”. College Quarterly, 11 (1).

Odede, I. O., \& Zawedde, N. (2018). Information Literacy Skills in using Electronic Information Resources. Library Philosophy and Practice (e-journal). University of Nebraska- Lincoln, November. https://www.researchgate.net/publication (December 6, 2019)

Olasore, R. E., \& Adekunmisi, S. R. (2015). Use of Library Electronic Information Resources by Academic Staff in Olabisi Onabanjo University". Global Advanced Research Journal of Educational Research Review, 4 (4), 055-062 April

Omar, A. M. (2012). The Role of University Library in Supporting Information Literacy. zulibrary.wordpress.com. (August 12, 2018) 